\title{
Simultaneous Estimation of Ibuprofen and Famotidine in Naturally Sweet Dispersible Pediatric Tablets by RP-HPLC
}

Dr. Vijay R Salunkhe*

Rajarambapu College of Pharmacy, Kasegaon, Taluka - Walwa, Sangli, Maharashtra 415409, India

DOI: 10.36348/sjmps.2019.v05i11.011 $\quad$ | Received: 18.11.2019| Accepted: 25.11.2019| Published: 28.11.2019

*Corresponding author: Dr. Vijay R Salunkhe

\section{Abstract}

A new simple, accurate, precise and reproducible RP-HPLC method has been developed for the simultaneous estimation of ibuprofen and famotidine in naturally sweet dispersible pediatric tablets using $\mathrm{C} 18$ column in isocratic mode. Methanol: buffer (90:10), pH 5, $25 \mathrm{mM}$; flow rate $0.9 \mathrm{ml} / \mathrm{min}$; column length: $25 \mathrm{~cm}$ is optimized. The flow rate was 1.0 $\mathrm{ml} / \mathrm{min}$ and detection wavelength was carried out at $284 \mathrm{~nm}$. The retention times of ibuprofen and famotidine were 5.293 min and 2.543 minutes respectively. The method was linear over the concentration range for ibuprofen $50-450 \mu \mathrm{g} / \mathrm{mL}$ and $2-18 \mu \mathrm{g} / \mathrm{mL}$ for ibuprofen and famotidine respectively. The recoveries of ibuprofen and famotidine were found to be in the range of $99.037-100.766 \%$ and $99.703-100.433 \%$ respectively. The validation of method was carried out utilizing ICH-guidelines. The described HPLC method was successfully employed for the analysis of pharmaceutical formulations containing combined dosage form.

Keywords: RP-HPLC method, Ibuprofen, Famotidine, naturally sweet, dispersible pediatric tablets.

Copyright @ 2019: This is an open-access article distributed under the terms of the Creative Commons Attribution license which permits unrestricted use, distribution, and reproduction in any medium for non-commercial use (NonCommercial, or CC-BY-NC) provided the original author and source are credited.

\section{INTRODUCTION}

The combination of Ibuprofen and Famotidine is approved combination in 2011 and is most effective and economic for the management of pain in rheumatoid arthritis [1]. Famotidine minimizes the ulcer [2] producing activity of Ibuprofen on repeated use in the treatment. The combination is official patent of Horizon pharma, Canada.

The dosage of the tablet is relatively large (800 $\mathrm{mg}$ Ibuprofen $-26.6 \mathrm{mg}$ Famotidine). There is no formulation developed for the pediatric patient suffering from juvenile rheumatoid arthritis. The formulation of naturally sweet fast dispersible tablet of Ibuprofen and Famotidine is convenient for the consumption of pediatric patients. Along with that, the dispersing time of less than $30 \mathrm{sec}$ produce quick action in the pain management, which is desirable.

There is no any method reported for the simultaneous estimation of the Ibuprofen and Famotidine in tablet dosage form. Our next aim is to develop a cheap, accurate, precise, reproducible and robust UV-spectrophotometric and HPLC method for the simultaneous estimation.
High performance liquid chromatography [3] is the fastest growing analytical technique for the analysis of drugs. Its simplicity, high specificity and wide range of sensitivity make it ideal for the analysis of many drugs in both dosage forms and biological fluid.

Ibuprofen [4] chemically is $\alpha$-Methyl-4-(2methylpropyl) benzeneacetic acidhaving molecular formula $\mathrm{c}_{13} \mathrm{~h}_{18} \mathrm{o}_{2}$ mol. wt. 206.3 is a non-steroidal anti-inflammatory medication used especially for the relief of the symptoms of arthritis, primary dysmenorrhea and fever, and as an analgesic, especially where there is an inflammatory component. Its side effects are gastrointestinal haemorrhage and ulceration.<smiles>CC(C)Cc1ccc(C(C)C(=O)O)cc1</smiles>

Famotidine [5] (FTD) is chemically 3-[(\{2[(diaminomethylidene) amino]-1, 3-thiazol-4-yl methyl) sulfanyl] - N' sulfamoyl propanimidamide. It is 
official in British Pharmacopoeia (BP, 2009) and United state Pharmacopoeia. It has an empirical formula $\mathrm{C}_{8} \mathrm{H}_{15} \mathrm{~N}_{7} \mathrm{O}_{2} \mathrm{~S}_{3}$ and a molecular weight of 337. It is an $\mathrm{H}_{2}$ blocker that works by reducing the amount of acid produced by the stomach because IB has a tendency to cause ulcers; It is added in combination to reduce the risk for ulcers (Merck Index, 1994). The combination dosage form of IB and FTD is available in the market and it is indicated in the treatment of Osteoarthritis and Rheumatoid arthritis. Because IB has a tendency to cause ulcers, FTD is added in combination to reduce the risk for ulcers.<smiles>NC(N)=Nc1nc(CSCC/C(N)=N/S(N)(=O)=O)cs1</smiles>

A literature survey [6] regarding quantitative analysis of these drugs revealed that attempts have been made to develop analytical methods for the estimation of IB alone and in combination with other drugs by liquid chromatographic, UPLC-MS/MS, HPTLC, super critical fluid chromatography and spectrophotometric methods, kinetic spectrophotometry potentiometric indications. For FTD Literature survey revealed that liquid chromatographic (LC) HPTLC and spectrophotometric methods have been reported for the estimation of FTD. However there is no method reported for the simultaneous estimation of these drugs in sweet pediatric dosage forms. Fixed dose combination containing IB and is available in the tablet form in the market. The aim of this work was to develop an HPLC method for the simultaneous estimation of IB and FTD in sweet pediatric dosage forms. The present method will be validated as per ICH guidelines.

\section{EXPERIMENTAL MATERIALS}

Ibuprofen was procured from Block pharma ltd. Kolhapur Famotidine from Cadila Healthcare Limited, Ahmedabad. HPLC grade methanol and acetonitrile were purchased from LOBA chemie Pvt. Ltd. Mumbai, The instruments used were UV spectro photometer (double beam) 1800 Shimadzu HPLC system (G4288A Compact LC model, software: EZ Chrome Elite) Agilent HPLC Column (Inertsil ODS$3 \mathrm{~V}, \mathrm{C} 18,4.6 \times 250 \mathrm{~mm}$ and $5 \mu \mathrm{m}$ particle size) GL Science Inc. Japan.

\section{High Performance Liquid Chromatographic Method [7] \\ Solubility Studies}

These studies were carried out to find a suitable and compatible solvent in which drugs are completely soluble. Different solvents like methanol, acetonitrile, chloroform were used for assessing the solubility of the Ibuprofen and Famotidine.

\section{Selection of Wavelength for Detection}

The wavelength for detection was selected by preparing the individual solution of $10 \mu \mathrm{g}$ of ibuprofen and famotidine and overlain spectra was produced using UV-Visible spectrophotometer. The selected wavelength was found to be $216 \mathrm{~nm}$.

\section{Selection of Stationary Phase}

By surveying the literature work and experimental work, the column selected on the basis of the separation achieved for the determination of the Ibuprofen and Famotidine. The column with the stationary phase specification providing best separation and peak shapes was selected for further studies.

\section{Optimization of Chromatographic Conditions [8]}

The HPLC procedure was optimized with a view to develop a good, accurate, precise, economic analytical method. Initially, different combinations of the mobile phases comprising of methanol, water, acetonitrile in different proportions were tried with modified $\mathrm{pH}$.

\section{Buffer Preparation}

1.7011 grams of potassium dihydrogen phosphate was dissolved in $500 \mathrm{ml}$ of double distilled water to get $0.025 \mathrm{M}$ solution. Solution was filtered through 0.45 micro meter filter and sonicate for $10 \mathrm{~min}$.

\section{Preparation of Mobile Phase}

Mobile phase was prepared by mixing potassium dihydrogen phosphate buffer and methanol in the ratio of 10:90 v/v. The $\mathrm{pH}$ of the mobile phase was adjusted to 5 with orthophosphric acid Mobile was filtered through 0.45 micro meter filter and subjected for degassing for 10 minute.

\section{Final Chromatographic Conditions}

The mobile phase was methanol-0.025 M aqueous potassium dihydrogenphosphate (90:10, v/v) adjusted to $\mathrm{pH} 5$ with phosphoric acid. Samples were dissolved in the mobile phase. The analysis was carried out under isocratic conditions using a flow rate of 0.9 $\mathrm{ml} / \mathrm{min}$, at room temperature $\left(27^{\circ} \mathrm{C}\right)$. Chromatograms were recorded at $216 \mathrm{~nm}$ using the UV detector.

\section{Preparation of standard stock solutions of the drug}

Stock solution of the drug (pure) was prepared by dissolving $50 \mathrm{mg}$ of each drug in $50 \mathrm{ml}$ of mobile phase in $50 \mathrm{ml}$ volumetric flask.

\section{Priming of the System}

Air in the conducting tubes was removed by manual method to obtain the continuous flow and to avoid the backpressure on the pump, avoiding the damage to the column. 


\section{Conditioning of the column}

Before a new run on HPLC, the warm $\left(40^{\circ} \mathrm{C}\right)$

HPLC water was run at flow rate of $1 \mathrm{ml} / \mathrm{min}$ for $1 \mathrm{hr}$, so as to remove water soluble impurities from on the column. Then the methanol and water in the ratio 50:50 was run at the same flow for $30 \mathrm{~min}$. conditioning of the column was done by passing methanol at $1 \mathrm{ml} / \mathrm{min}$ flow rate for $30 \mathrm{~min}$. so as to remove all the remains of the previous run.

\section{Loading of Mobile Phase}

Filtered and degassed mobile phase was thus filled in the reservoir. Priming was done for each freshly prepared mobile phase.

\section{Baseline Stabilization}

The detector was turned on for two min before the actual run so as to obtain the stable UV light. The mobile phase run was started at required flow rate and the run was continued so as to obtain the stable baseline.

\section{Calibration Curve}

Calibration curves were prepared by taking appropriate aliquots of standard ibuprofen and famotidine stock solutions in different $10 \mathrm{ml}$ volumetric flask and diluted up to the mark with mobile phase to obtain final concentrations in the range of $50 \mu \mathrm{g} / \mathrm{ml}$ to $450 \mu \mathrm{g} / \mathrm{ml}$ of ibuprofen and $2 \mu \mathrm{g} / \mathrm{ml}$ to $18 \mu \mathrm{g} / \mathrm{ml}$ of famotidine. The samples were filtered through $0.45 \mu \mathrm{m}$ syringe filter and subjected to sonication for $10 \mathrm{~min}$. Volume of $20 \mu \mathrm{L}$ of each sample was injected with the help of manual injector. Calibration curve was constructed by plotting the peak area vs. the drug concentration and regression equation was computed.

\section{Quantitation Method}

The external standard calibration method was used for calibration. The external standard is the same substance as that being analyzed in the sample. In this method, by injecting standard solution in different concentrations, peak response vs. concentration was plotted. Unknown sample was analyzed in similar manner and their concentrations determined from the calibration curve. The calibration curve was observed to cover the range of unknown samples.

\section{Application of proposed method to standard drug mixture}

The standard drug mixture was prepared by diluting the standard stock solution with mobile phase to get the final concentration of $100 \mu \mathrm{g} / \mathrm{mL}$ and $3.32 \mu \mathrm{g} / \mathrm{mL}$ of ibuprofen and famotidine respectively. The prepared standard mixture solution was filtered through $0.45 \mu \mathrm{m}$ syringe filter and subjected to sonication for $10 \mathrm{~min}$. Volume of $20 \mu \mathrm{L}$ of standard mixture solution was injected with the help of manual injector.

\section{Application of proposed method to Test sample}

Two formulated tablets containing ibuprofen and famotidine (Label claim: famotidine-13.3 mg, ibuprofen- $400 \mathrm{mg}$ ) were taken and powdered. The powder equivalent to $100 \mathrm{mg}$ of ibuprofen was dissolved in $100 \mathrm{ml}$ of mobile phase to get a stock solution of 1 $\mathrm{mg} / \mathrm{ml}$ and then sonicated for $15 \mathrm{~min}$. This solution was filtered through a membrane filter. The solution was further diluted stepwise with mobile phase to get the final concentration of $100 \mu \mathrm{g} / \mathrm{mL}$ for ibuprofen and $3.32 \mu \mathrm{g} / \mathrm{mL}$ for famotidine respectively. The prepared test sample solution was filtered through $0.45 \mu \mathrm{m}$ syringe filter and subjected to sonication for $10 \mathrm{~min}$. Volume of $20 \mu \mathrm{L}$ of test sample solution was injected with the help of manual injector. The chromatogram obtained from sample solution was compared with the standard chromatogram and amount of the drug present in the formulation was calculated.

The proposed method was validated as per ICH guidelines [9]. The solutions of the drugs were prepared as per the earlier adopted procedure given in the experiment.

\section{Linearity}

Linearity was studied by preparing serial dilutions prepared using standard stock solution. Dilutions were prepared by taking appropriate aliquots of standard ibuprofen and famotidine stock solutions in different $10 \mathrm{ml}$ volumetric flask and diluted up to the mark with mobile phase to obtain final concentrations in the range of $50 \mu \mathrm{g} / \mathrm{ml}$ to $450 \mu \mathrm{g} / \mathrm{ml}$ of ibuprofen and $2 \mu \mathrm{g} / \mathrm{ml}$ to $18 \mu \mathrm{g} / \mathrm{ml}$ of famotidine.

\section{Specificity and Selectivity}

The analytes should have no interference from other extraneous components and be well resolved from them. Specificity is a procedure to detect quantitatively the analyte in presence of component that may be expected to be present in the sample matrix, while selectivity is the procedure to detect qualitatively the analyte in presence of components that may be expected to be present in the sample matrix. Volume of $20 \mu \mathrm{l}$ of standard solution having concentration 100 $\mu \mathrm{g} / \mathrm{ml}$ of Ibuprofen and $3.32 \mu \mathrm{g} / \mathrm{ml}$ of Famotidine was injected in HPLC system. Similarly, volume of $20 \mu \mathrm{l}$ of test preparation having concentration $100 \mu \mathrm{g} / \mathrm{ml}$ of Ibuprofen and $3.32 \mu \mathrm{g} / \mathrm{ml}$ of Famotidine was injected in HPLC system.

\section{Accuracy}

To determine the accuracy of the proposed method, recovery studies were carried out by adding different amounts $(80 \%, 100 \%$, and $120 \%)$ of bulk samples of ibuprofen and famotidine within the linearity range were taken and added to the preanalyzed formulation containing concentration of 100 
$\mu \mathrm{g} / \mathrm{ml}$ for ibuprofen and $3.32 \mu \mathrm{g} / \mathrm{ml}$ for famotidine. From that percentage recovery values were calculated.

\section{Precision}

Precision an analytical procedure expresses the closeness of agreement between a series of measurements obtained from multiple sampling of the same homogeneous sample under the prescribed conditions.

\section{Repeatability}

It expresses the precision under same operating conditions over short interval of time. It is termed as intra-assay precision.

It is measured by multiple injections of a homogenous test sample having concentration 100 $\mu \mathrm{g} / \mathrm{ml}$ ibuprofen and $3.32 \mu \mathrm{g} / \mathrm{ml}$ famotidine indicates the performance of the HPLC instrument under chromatographic conditions.

\section{Intermediate Precision}

The intermediate precision was carried out by analyzing the same sample of standard mixture applying typical variations including days, analysts, equipment, etc. at same operating conditions as per the test method i.e. flow rate $0.9 \mathrm{ml} / \mathrm{min}$, room temperature $27^{0} \mathrm{C}$.

The precision of each method was ascertained separately from the peak areas obtained by actual determination of six replicates of a fixed amount of drug. The standard deviation and percentage relative standard deviations were calculated for ibuprofen and famotidine and presented in the table 38. The precision of the assay was also determined in terms of intra-and inter-day variation in the peak areas for a set of drug solutions on three different days. The intra-and interday variation in the peak area of the drug solution was calculated in terms of SD, \% RSD.

\section{Robustness}

It is measure of its capacity to remain unaffected by small but deliberate change in method parameters and provides an indication of its reliability in normal usage. The parameters for HPLC method include the variation in flow rate, mobile phase composition, $\mathrm{pH}$.

\section{Effect of Mobile Phase Composition Variation}

By changing the composition of aqueous phase from $90 \%(91: 09)$ and $110 \%(89: 11)$ instead of $100 \%$ (90:10) aqueous phase, Robustness of ibuprofen and famotidine assay method was checked by injecting the 3 replicate injections (volume $20 \mu \mathrm{l}$ ) of standard $(100 \mu \mathrm{g} / \mathrm{ml}$ ibuprofen and $3.32 \mu \mathrm{g} / \mathrm{ml}$ famotidine) in $90 \%$ and $110 \%$ aqueous phase composition.

\section{Effect of PH Variation}

Robustness of the method was checked by changing $\mathrm{PH}$ of mobile phase 4.8 to 5.2 instead of 5 by injecting the 3 replicate injections (volume $20 \mu \mathrm{l}$ ) of standard $(100 \mu \mathrm{g} / \mathrm{ml}$ ibuprofen and $3.32 \mu \mathrm{g} / \mathrm{ml}$ famotidine) at PH 4.8 and 5.2 of mobile phase.

\section{Effect of Flow Rate Variation}

Robustness of the method was checked by changing flow rate from $0.8 \mathrm{ml} / \mathrm{min}$ to $1 \mathrm{ml} / \mathrm{min}$ instead of $0.9 \mathrm{ml} / \mathrm{min}$ by injecting the 3 replicate injection (volume $20 \mu \mathrm{l})$ standard $(100 \mu \mathrm{g} / \mathrm{ml}$ ibuprofen and $3.32 \mu \mathrm{g} / \mathrm{ml}$ famotidine) at $0.8 \mathrm{ml} / \mathrm{min}$ and $1 \mathrm{ml} / \mathrm{min}$.

\section{Ruggedness Study}

Ruggedness of the methods was assessed by carrying out assay six times with two different analyst by using same equipment.

\section{System Suitability Parameters}

System suitability parameters can be defined as tests to ensure that the method can generate results of acceptable accuracy and precision. The requirements for system suitability are usually developed after method development and validation has been completed or The USP (2000) defines parameters that can be used to determine system suitability prior to analysis. The system suitability parameters like Theoretical plates $(\mathrm{N})$, Resolution (R), Asymmetry, LOD $(\mu \mathrm{g} / \mathrm{ml})$ and LOQ $(\mu \mathrm{g} / \mathrm{ml})$ were calculated and compared with the standard values to ascertain whether the proposed RPHPLC method for the estimation of ibuprofen and famotidine in bulk and formulated tablet dosage form was validated or not.

\section{Analysis of Prepared Formulation}

Ten tablets were weighed accurately and finely powdered. Tablet powder equivalent to $800 \mathrm{mg}$ IB and $26.6 \mathrm{mg}$ of FTD was taken in $100 \mathrm{ml}$ volumetric flask. Methanol $(20 \mathrm{ml})$ was added to the above flask and the flask was sonicated for 30 minutes. The solution was filtered using whatman filter paper No.1 and volume was made up to the mark with distilled water. From this solution prepare working solutions they have concentration $10 \mu \mathrm{g} / \mathrm{ml}$ of IB and $6 \mu \mathrm{g} / \mathrm{ml}$ of FTD.

\section{Detection Limit}

The Detection Limit of an individual analytical procedure is the lowest amount of analyte in a sample which can be detected but not necessarily quantitated as an exact value. The detection limit (LOD) may be expressed as: $\mathrm{LOD}=3.3 \sigma \mathrm{S}$ Where $=$ Relative standard deviation of the response. $\sigma \mathrm{S}=$ the slope of the calibration curve (of the analyte).

\section{Quantitation Limit}

The Quantitation limit of an analytical procedure is the lowest amount of analyte in a sample, which can be quantitatively determined with suitable precision and accuracy. Quantitation Limit (LOQ) may 
be expressed as: $\sigma \mathrm{LOQ}=10 \mathrm{~S}$ Where $=$ Relative standard deviation of the response. $\sigma \mathrm{S}=$ the slope of the calibration curve (of the analyte).

\section{RESULTS AND DISCUSSION}

\section{Solubility studies [10]}

After assessing the solubility of drugs in different solvents it was found that after two minutes of sonication both ibuprofen and famotidine were found to be soluble in methanol, hence methanol was selected for further studies.

\section{Selection of Wavelength for Detection}

After studying the overlain spectra of ibuprofen and famotidine using UV-Visible spectrophotometer, the wavelength $216 \mathrm{~nm}$ selected for the further studies.
On the basis of results obtained, reversed phase HPLC mode stationary phase column with $\mathrm{C} 18$ bonded phase i.e. - Inertsil ODS-3V, C18, 4.6×250 mm and $5 \mu \mathrm{m}$ particle size was used for separation.

\section{Optimization of chromatographic conditions}

Different mobile phases and column with different length were tried to achieve best separation and peak shape. Methanol: buffer (90:10), pH 5, 25 $\mathrm{mM}$; flow rate $0.9 \mathrm{ml} / \mathrm{min}$; column length: $25 \mathrm{~cm}$.

The given mobile phase had produced acceptable and satisfactory results amongst all the tried hence above mobile phase is used for further studies.

\section{Validation of the Developed Methods [11] Linearity}

The linearity range was found to be in between $50-450 \mu \mathrm{g} / \mathrm{mL}$ and $2-18 \mu \mathrm{g} / \mathrm{mL}$ for ibuprofen and famotidine respectively. The linearity data for method is presented in Table 1 and 2 and Figures 1 and 2 respectively.

\section{Selection of Stationary Phase}

Table-1: Linearity data for Ibuprofen

\begin{tabular}{|l|l|l|l|}
\hline Ibuprofen conc. $(\boldsymbol{\mu g} / \mathbf{m L})$ & Avg. peak area* & Standard deviation* & \% RSD \\
\hline 50 & 40462508 & 542469.7 & 1.340 \\
\hline 100 & 81807965 & 568107.1 & 0.694 \\
\hline 150 & 122236800 & 1882037 & 1.539 \\
\hline 200 & 158323037 & 1647578 & 1.040 \\
\hline 250 & 196979864 & 3011672 & 1.528 \\
\hline 300 & 237352736 & 2730571 & 1.150 \\
\hline 350 & 279343366 & 2068523 & 0.740 \\
\hline 400 & 316209470 & 4971847 & 1.572 \\
\hline 450 & 352694121 & 4357276 & 1.235 \\
\hline Avg. Standard Deviation & & 2178008 & \\
\hline Avg. \% RSD & & & 1.204 \\
\hline
\end{tabular}

Table-2: Linearity data for Famotidine

\begin{tabular}{|l|l|l|l|}
\hline Famotidine conc. $(\boldsymbol{\mu g} / \mathbf{m L})$ & Avg. peak area* & Standard deviation* & \% RSD \\
\hline 2 & 2475837.5 & 36796.26 & 1.486 \\
\hline 4 & 4975903.7 & 43582.99 & 0.875 \\
\hline 6 & 7337772.2 & 100308.9 & 1.367 \\
\hline 8 & 9490132.7 & 81384.37 & 0.857 \\
\hline 10 & 12178902 & 154238.9 & 1.266 \\
\hline 12 & 13976580 & 157823.2 & 1.129 \\
\hline 14 & 16771302 & 167423.4 & 0.998 \\
\hline 16 & 19090081 & 198070.7 & 1.037 \\
\hline 18 & 20798672 & 172852.9 & 0.831 \\
\hline Avg. SD & 111248.2 & \\
\hline Avg. \% RSD & & 1.094 \\
\hline
\end{tabular}




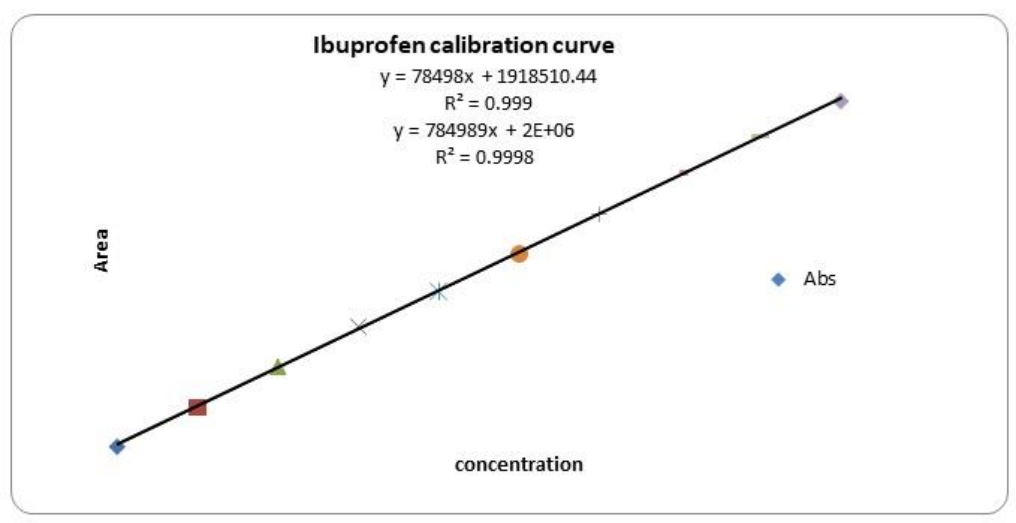

Fig-1: Calibration curve of ibuprofen

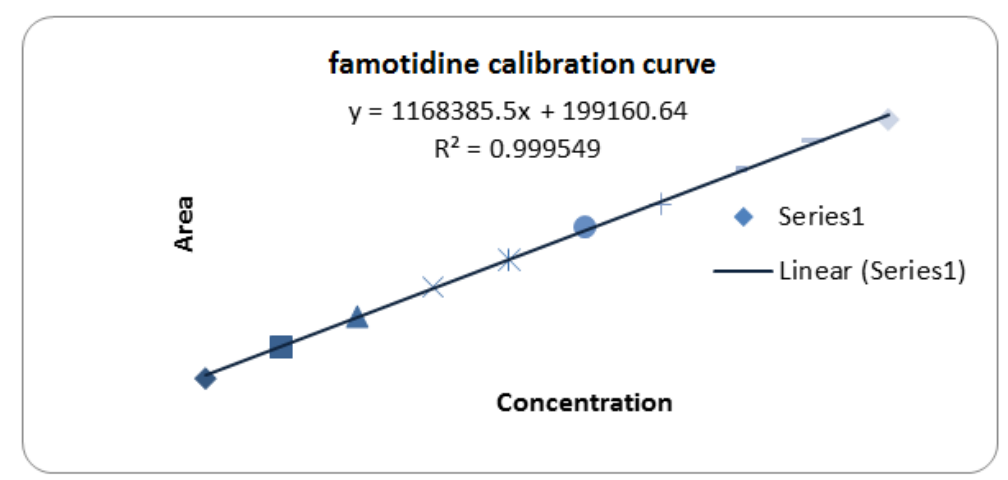

Fig-2: Calibration curve of famotidine

\section{Analysis of Formulations}

The amount of drugs present in each bulk and formulated tablet dosage form were calculated through peak areas of drugs by using the standard calibration curve (concentration in $\mu \mathrm{g} / \mathrm{ml}$ was taken on $\mathrm{x}$-axis and peak areas on y-axis). The results were shown in Table 1 and 2. A typical chromatogram of ibuprofen and famotidine in bulk and formulation was shown in Figures 3 and 4 .

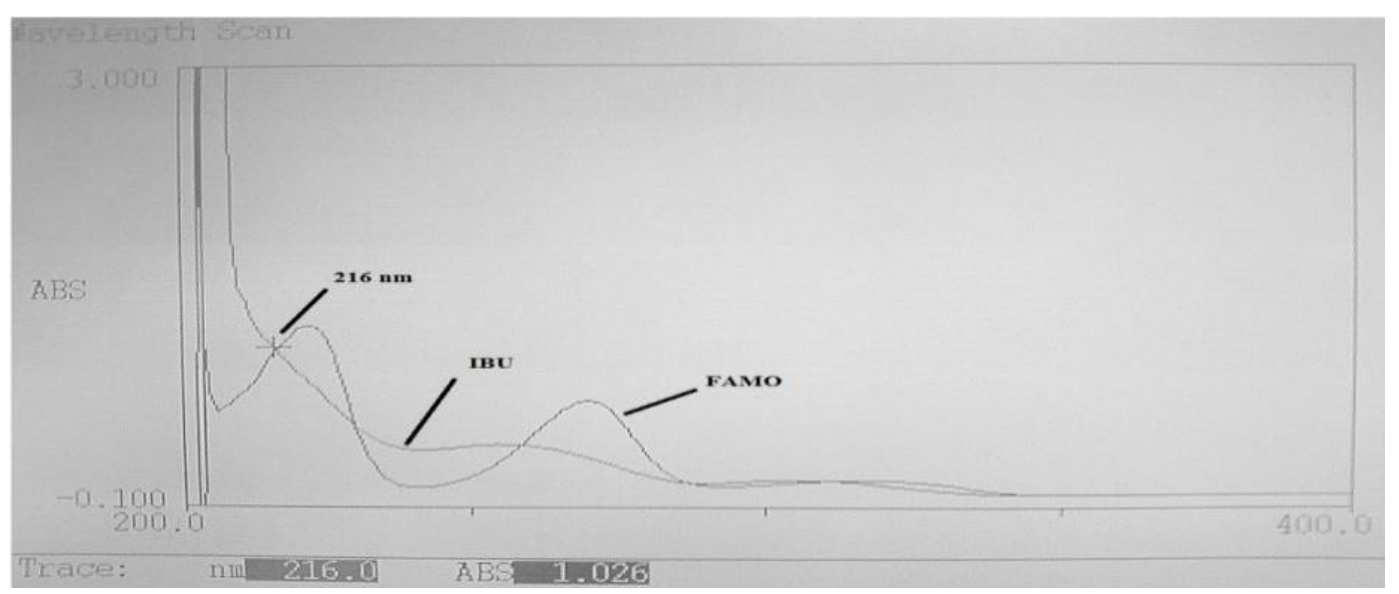

Fig-3: Overlain spectra of Ibuprofen and Famotidine pure drugs 


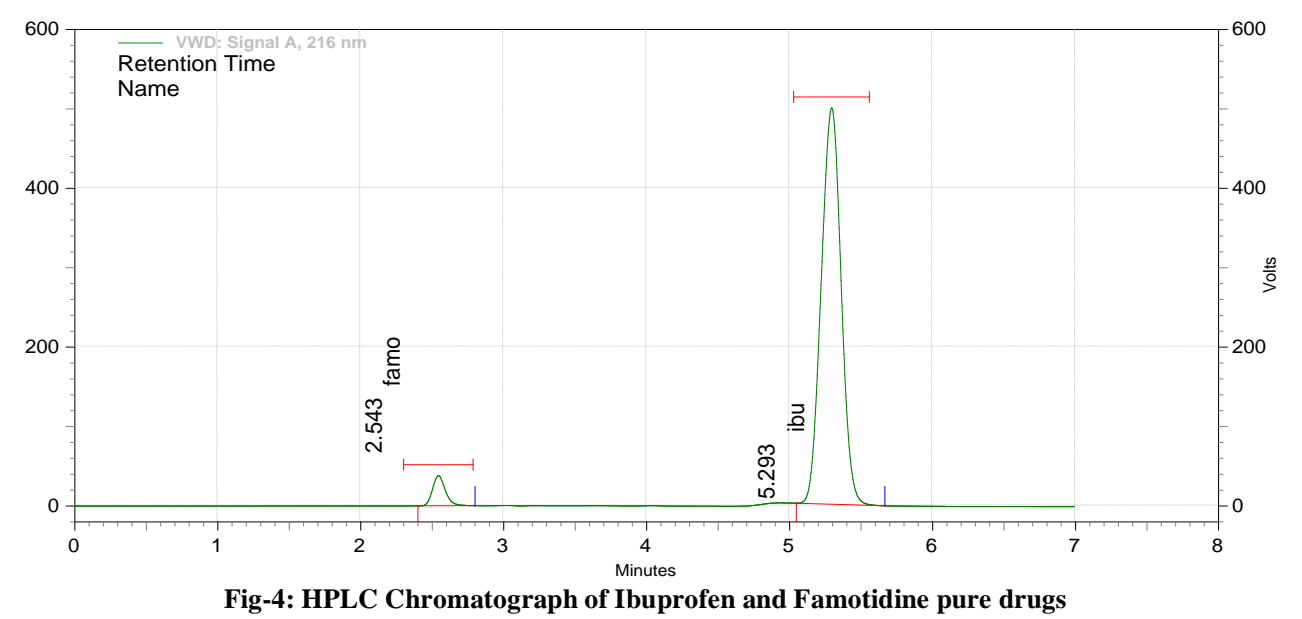

\section{Specificity and Selectivity}

The analytes shown no interference from other extraneous components and were well resolved from them.

Retention time for-----

Famotidine

$2.487 \mathrm{~min}$

Ibuprofen

$5.227 \mathrm{~min}$
The values obtained were very close to that in standard laboratory mixture indicates that no interference from the component of matrix.

Accuracy

The results are shown in Table-3.

Table-3: Results of Accuracy

\begin{tabular}{|l|l|l|l|l|}
\hline $\begin{array}{l}\text { Concentration of the drug added to the } \\
\text { formulation }\end{array}$ & $\begin{array}{l}\text { Ibuprofen \% Recovery } \\
\mathbf{\pm} \text { SD* }\end{array}$ & \%RSD & $\begin{array}{l}\text { Famotidine \% Recovery } \\
\pm \text { SD* }\end{array}$ & RSD \\
\hline $80 \%$ & $98.43 \pm 0.4791$ & 0.486 & $99.59 \pm 1.2266$ & \\
\hline $100 \%$ & $100.86 \pm 1.3051$ & 1.293 & $97.71 \pm 1.3706$ & 1.231 \\
\hline $120 \%$ & $99.68 \pm 0.6188$ & 0.620 & $102.18 \pm 1.1081$ & 1.402 \\
\hline
\end{tabular}

\section{Recovery}

The results are shown in Table- 4 .

Table-4: Analysis and recovery of Ibuprofen and famotidine formulated tablets

\begin{tabular}{|l|l|l|l|l|}
\hline Formulation & Drug & Label Claim & Amount found \pm S.D & \% \\
\hline Tablet & Ibuprofen & $400 \mathrm{mg}$ & $394.16 \pm 6.075$ & $98.54 \pm 1.518$ \\
\cline { 2 - 5 } & Famotidine & $13.3 \mathrm{mg}$ & $13.325 \pm 0.196$ & $100.19 \pm 1.474$ \\
\hline
\end{tabular}

\section{Precision}

The intra-and inter-day variation in the peak area of the drug solution was calculated in terms of SD, \% RSD. The results are shown in Table-5.

Table-5: The intra-and inter-day variation in the peak area of the drug solution was calculated in terms of SD, \% RSD

\begin{tabular}{|c|c|c|c|c|c|c|}
\hline \multicolumn{4}{|c|}{ Intraday precision } & \multicolumn{2}{|c|}{ Interday precision } & \\
\hline & $\begin{array}{l}\text { Amount found } \pm \\
\text { S.D* }(\mu \mathrm{g} / \mathrm{mL})\end{array}$ & $\begin{array}{l}\% \text { Amount } \\
\text { found } \pm \text { S.D* }\end{array}$ & $\begin{array}{l}\% \\
\text { RSD }\end{array}$ & $\begin{array}{l}\text { Amount found } \pm \\
\text { S.D* }(\mu \mathrm{g} / \mathrm{mL})\end{array}$ & $\begin{array}{l}\% \quad \text { Amount } \\
\text { found } \pm \text { S.D* }\end{array}$ & $\begin{array}{l}\% \\
\text { RSD }\end{array}$ \\
\hline $\begin{array}{l}\text { Ibuprofen } \\
(100 \mu \mathrm{g} / \mathrm{mL})\end{array}$ & $100.30 \pm 1.065$ & $100.30 \pm 1.065$ & 1.068 & $97.01 \pm 0.845$ & $97.01 \pm 0.845$ & 0.871 \\
\hline $\begin{array}{l}\text { Famotidine } \\
(3.32 \mu \mathrm{g} / \mathrm{mL})\end{array}$ & $3.29 \pm 0.038$ & $100.87 \pm 1.156$ & 1.171 & $3.21 \pm 0.008$ & $96.81 \pm 0.247$ & 0.256 \\
\hline
\end{tabular}

\section{Robustness}

The results are shown in Table-6. 
Vijay R Salunkhe; Saudi J Med Pharm Sci, Nov., 2019; 5(11): 983-991

Table-6: Robustness study for Ibuprofen and famotidine

\begin{tabular}{|l|l|l|l|l|}
\hline \multirow{2}{*}{ Chromatographic Condition } & \multicolumn{3}{l}{ Ret. Time* } & \multicolumn{1}{l|}{ Asymmetry* } \\
\cline { 2 - 5 } & IBU & FAMO & \multicolumn{1}{l|}{ IBU } & FAMO \\
\hline \multicolumn{5}{|c|}{ A] Flow Rate } \\
\hline 0.8 & 5.311 & 2.548 & 1.001 & 1.204 \\
\hline 0.9 & 5.359 & 2.505 & 1.048 & 1.293 \\
\hline 1.0 & 5.224 & 2.488 & 1.022 & 1.308 \\
\hline Avg. & 5.298 & 2.514 & 1.024 & 1.269 \\
\hline SD & 0.0348 & 0.0161 & 0.0176 & 0.0198 \\
\hline$\%$ RSD & 0.651 & 0.645 & 1.718 & 1.568 \\
\hline \multicolumn{5}{|c|}{ B] Bufler $:$ Methanol (v/v) } \\
\hline $9: 91$ & 5.224 & 2.488 & 1.026 & 1.305 \\
\hline $10: 90$ & 5.265 & 2.521 & 1.023 & 1.264 \\
\hline $11: 89$ & 5.337 & 2.547 & 1.005 & 1.198 \\
\hline Avg. & 5.275 & 2.518 & 1.018 & 1.256 \\
\hline SD & 0.0165 & 0.0066 & 0.0179 & 0.0234 \\
\hline$\%$ RSD & 0.311 & 0.266 & 1.767 & 1.862 \\
\hline \multicolumn{5}{|c|}{ D] PH effect } \\
\hline 4.5 & 5.342 & 2.35 & 1.073 & 1.186 \\
\hline 5 & 5.232 & 2.499 & 1.026 & 1.284 \\
\hline 5.5 & 5.288 & 2.533 & 1.012 & 1.217 \\
\hline Avg. & 5.287 & 2.460 & 1.037 & 1.229 \\
\hline SD & 0.0099 & 0.0118 & 0.0102 & 0.0134 \\
\hline$\%$ RSD & 0.188 & 0.473 & 0.988 & 1.083 \\
\hline
\end{tabular}

Ruggedness study

The results are shown in Table-7.

Table-7: Ruggedness study

\begin{tabular}{|l|l|l|l|l|}
\hline Formulation & Drug & Label Claim & Amount found \pm S.D & \% label claim \pm S.D \\
\hline \multirow{2}{*}{ Analyst 1} & Ibuprofen & $400 \mathrm{mg}$ & $409.67 \pm 3.160$ & $102.41 \pm 0.790$ \\
\cline { 2 - 5 } & Famotidine & $13.3 \mathrm{mg}$ & $12.68 \pm 0.194$ & $95.34 \pm 1.464$ \\
\hline \multirow{2}{*}{ Analyst 2} & Ibuprofen & $400 \mathrm{mg}$ & $408.05 \pm 3.017$ & $102.0140 \pm 0.754$ \\
\cline { 2 - 5 } & Famotidine & $13.3 \mathrm{mg}$ & $12.57 \pm 0.080$ & $94.55 \pm 0.608$ \\
\hline
\end{tabular}

\section{System Suitability Parameters}

The results are shown in Table- 8 .

Table-8: System suitability parameters

\begin{tabular}{|l|l|l|}
\hline \multirow{2}{*}{ Parameters } & \multicolumn{2}{|l|}{ Obtained Values } \\
\cline { 2 - 3 } & Ibuprofen & famotidine \\
\hline Theoretical plates $(\mathrm{N})$ & 8629 & 4814 \\
\hline Resolution $(\mathrm{R})$ & 14.89 & \\
\hline Asymmetry & 1.038 & 1.260 \\
\hline LOD $(\mu \mathrm{g} / \mathrm{ml})$ & 9.156 & 0.3146 \\
\hline LOQ $(\mu \mathrm{g} / \mathrm{ml})$ & 27.745 & 0.9533 \\
\hline
\end{tabular}

\section{Limit of Detection}

It is done as per procedure given in experimental work section. The results of the same are presented in Table 9 and 10.

\section{Limit of Quantitation}

It is done as per procedure given in experimental work section. The results of the same are presented in Table 9 and 10.

Table-9: Data for LOD and LOQ of Ibuprofen

\begin{tabular}{|l|l|l|l|}
\hline Sr. No. & Concentration $[\boldsymbol{\mu g} / \mathbf{m l}]$ & Absorbance of Ibuprofen & Standard deviation* \\
\hline 1 & 20 & 0.048 & 0.000816 \\
\hline 2 & 40 & 0.088 & 0.001528 \\
\hline 3 & 60 & 0.128 & 0.000577 \\
\hline 4 & 80 & 0.17 & 0.003215 \\
\hline 5 & 100 & 0.218 & 0.001 \\
\hline 6 & 120 & 0.249 & 0.001 \\
\hline 7 & 140 & 0.292 & 0.000516 \\
\hline \multicolumn{2}{|l|}{ Avg. Standard Deviation } & & 0.001027 \\
\hline \multicolumn{2}{|l|}{ slop } & & 0.002072 \\
\hline
\end{tabular}

Table-10: Data for LOD and LOQ of Famotidine

\begin{tabular}{|l|l|l|}
\hline Drug & LOD $(\boldsymbol{\mu g} / \mathbf{m l})$ & LOQ $(\boldsymbol{\mu g} / \mathbf{m l})$ \\
\hline Ibuprofen & 1.7232 & 5.2220 \\
\hline Famotidine & 0.087 & 0.2646 \\
\hline
\end{tabular}


Table-12: Summary of the results of Validation parameters

\begin{tabular}{|c|c|c|c|}
\hline \multicolumn{2}{|l|}{ Parameters } & Ibuprofen & Famotidine \\
\hline \multicolumn{2}{|c|}{ Detection wavelength } & $265 \mathrm{~nm}$ & $287 \mathrm{~nm}$ \\
\hline \multicolumn{2}{|l|}{ Linearity range } & $20-140 \mu \mathrm{g} / \mathrm{mL}$ & $2-10 \mu \mathrm{g} / \mathrm{mL}$ \\
\hline \multicolumn{2}{|l|}{ Slope } & 0.002072 & 0.049386 \\
\hline \multicolumn{2}{|l|}{ Intercept } & 0.004083 & 0.001905 \\
\hline \multicolumn{2}{|c|}{ Correlation coefficient } & 0.9993 & 0.99993 \\
\hline \multicolumn{2}{|c|}{ Regression equation } & $Y=0.002 x-0.004$ & $Y=0.049 x-0.0019$ \\
\hline \multicolumn{2}{|c|}{ Limit of detection } & $1.7232 \mu \mathrm{g} / \mathrm{mL}$ & $0.087 \mu \mathrm{g} / \mathrm{mL}$ \\
\hline \multicolumn{2}{|c|}{ Limit of quantitation } & $5.2220 \mu \mathrm{g} / \mathrm{mL}$ & $0.2646 \mu \mathrm{g} / \mathrm{mL}$ \\
\hline \multicolumn{2}{|l|}{ Assay $(\%)$} & $99.53 \pm 0.393$ & $98.71 \pm 0.3227$ \\
\hline \multicolumn{2}{|l|}{ Recovery (\%) } & $100.43 \pm 0.4376$ & $101.95 \pm 0.578$ \\
\hline \multirow[t]{2}{*}{ Precision (\%) } & Intraday & $100.55 \pm 0.7023$ & $99.58 \pm 0.8759$ \\
\hline & Interday & $99.80 \pm 0.574$ & $98.76 \pm 0.3893$ \\
\hline \multirow[t]{2}{*}{ Ruggedness } & Analyst 1 & $100.7 \pm 0.617$ & $100.16 \pm 0.276$ \\
\hline & Analyst 2 & $99.58 \pm 0.8049$ & $98.66 \pm 0.3076$ \\
\hline
\end{tabular}

\section{SUMMARY AND CONCLUSION}

The analytical methods for the determination of Ibuprofen and Famotidine in bulk drug and sweet pediatric dosage form RP-HPLC have been developed and validated as per the ICH guidelines for analytical method validation.

A simple and rapid RP-high performance liquid chromatographic method was developed for the separation and determination of ibuprofen and famotidine from bulk drug and formulated tablet dosage form. The separation was achieved on a reversed-phase $\mathrm{C}_{18} \quad(\mathrm{ODS}-3 \mathrm{~V}, \quad 4.6 \times 250 \mathrm{~mm}, 5 \mu \mathrm{m})$ column using Methanol-0.025 $\mathrm{M}$ aqueous potassium dihydrogen phosphate $(90: 10, \mathrm{v} / \mathrm{v} ; \mathrm{pH} 5)$ as eluent. The mean recovery of ibuprofen and famotidine from samples was $98.54 \pm 1.51 \% \mathrm{w} / \mathrm{v}$ and $100.19 \pm 1.47 \% \mathrm{w} / \mathrm{v}$. The limit of detection was found to be $9.156 \mu \mathrm{g} / \mathrm{mL}$ and $0.3146 \mu \mathrm{g} / \mathrm{mL}$ for ibuprofen and famotidine respectively.

RP-HPLC methods for the determination of Ibuprofen and Famotidine in formulated tablet dosage forms were developed and validated as per the requirement of $\mathrm{ICH}$ guidelines. The methods found to be simple, economic, precise, accurate and rapid, providing a reliable and accurate determination of ibuprofen and famotidine in pure and formulated tablet dosage form.

\section{REFERENCES}

1. Abdel-Nasser, A. M., Rasker, J. J., \& Vaikenburg, H. A. (1997, October). Epidemiological and clinical aspects relating to the variability of rheumatoid arthritis. In Seminars in arthritis and rheumatism, 27(2):123-140.

2. Bingham Clifton O III (John Hopkins arthritis center), Rheumatoid Arthritis Treatment.

3. Rudis, J. (2011). Juvenile Rheumatoid Arthritis, Nucleus Medical Media, Inc.
4. Tidmarsh, G., Golombik, B. L., \& Sharma P. (2009). Patent application title: Methods and Medicaments for Administration of Ibuprofen, Inventors: Horizon Therapeutics, Inc., Publication date: 10/22/2009, patent application number: 20090264484.

5. Biffar, S. E., \& Mazzo, D. J. (1986). Reversedphase determination of famotidine, potential degradates, and preservatives in pharmaceutical formulations by high-performance liquid chromatography using silica as a stationary phase. Journal of Chromatography A, 363(2), 243249.

6. Battu, P. R., \& Reddy, M. S. (2009). RP-HPLC method for simultaneous estimation of paracetamol and ibuprofen in tablets. Asian Journal of Research in Chemistry, 2(1), 70-72.

7. Ge, Z. K., Luo, Y. H., Zhao, X. Y., Zhang, Y. J., Zhang, H., \& Tian, C. C. (2011). Simultaneous determination of ibuprofen and diphenhydramine $\mathrm{HCl}$ in orally disintegrating tablets and its dissolution by reversed-phase high performance liquid chromatography (RP-HPLC). African Journal of Pharmacy and Pharmacology, 5(18), 2100-2105.

8. Husain, S., Khalid, S., Nagaraju, V., \& Rao, R. N. (1996). High-performance liquid chromatographic separation and determination of small amounts of process impurities of famotidine in bulk drugs and formulations. Journal of Chromatography A, 743(2), 328-334.

9. ICH, Q2A. (1994). Text on validation of analytical procedures, International Conference on Harmonization.

10. Indian pharmacopoeia. (2007). The Controller of Publications, Govt. of India, New Delhi, Vol-II: 1217.

11. ICH, Q3B. (1996). Validation of analytical procedures: Methodology, International Conference on Harmonization. 